\title{
POSSIBLE IMPACT OF THE LATEST INTERNATIONAL STANDARD OF AUDITING 570 ON THE RATE OF GOING CONCERN OPINION ISSUANCE IN MALAYSIA
}

\author{
Mohammad Noor Hisham Osman ${ }^{1}$, Ahmed Razman Abdul Latiff ${ }^{2}$, Zaidi Mat Daud ${ }^{3}$, Zulkarnain \\ Muhamad Sori ${ }^{4}$, Siti Zaidah Turmin ${ }^{5}$ \\ 1,3,5 Department of Accounting and Finance, Faculty of Economics and Management, \\ Universiti Putra Malaysia, 43400 Serdang, Selangor \\ ${ }^{2}$ Putra Business School, 43400 Serdang, Selangor \\ ${ }^{4}$ International Centre for Education in Islamic Finance (INCEIF), \\ Lorong Universiti A, 59100 Kulala Lumpur \\ *Corresponding E-mail : mhisham@upm.edu.my
}

\begin{abstract}
Auditors are required to issue going concern opinion (GC opinion) to companies that are incapable to continue their operations in the near future. It is very important for auditors to issue the GC opinion properly because such opinion is the only signal from them on the viability of a company. Investors need such signal before they can make good investment decisions. In Malaysia however, auditors do not want to issue GC opinion to a very large percentage of financially distressed companies. This motivates this paper to discuss the impact of the latest ISA 570 (2016) on GC opinion issuance rate in this country. Overall, we are in the opinion that there is no strong ground to expect the new ISA 570 (2016) to reduce the problem of Malaysian auditors do not issue the GC opinion to many financially distressed companies. This is due to no new stricter measures being introduced in the latest auditing standard. Nonetheless, we propose four actions that can be taken by Malaysian policy makers and standard setters if they want to improve the rate and practice of GC opinion issuance.
\end{abstract}

Keywords: Going Concern Opinion, ISA 570, Audit Quality

DOI: https://doi.org/10.30880/jtmb.2018.05.02.008

Received: April 19, 2018

Accepted: June 11, 2018

Published: June 15, 2018

\subsection{Background}

The incidents that Malaysian auditors do not issue going concern opinion (GC opinion) to seriously financially distressed companies is still a pressing problem. A survey conducted by Osman, Turmin, Muhamad and Hussain (2016) reported that auditor issued GC opinion to only between 11 and 30 percent of financially distress Malaysian properties and construction listed companies. Earlier, Abdul Wahab, Mat Zain and Abdul Rahman (2013) analysed data of selected 379 financially distress companies and found that only 6.3 percent of them received GC opinion. Policy makers have raised this issue as early as in 2009 (and until recently). Financial Statement Review Committee (FSRC) of Malaysian Institute of Accountant, particularly, reveals that the most common weakness in Malaysian listed companies' financial statements under their selective review is in the assessment of the appropriateness of GC assumption during the preparation of the documents (see Accountants Today, December 2009, May/June 2012, November 2010, November, 2009).

The latest International Standards on Auditing 570 Going Concern (ISA 570) has been released and made effective in Malaysia starting from $15^{\text {th }}$ December 2016. It is reasonable to expect that the new ISA 570 (2016) could at least reduce the incidence of Malaysian auditors do not want to issue GC opinion 
to financially distress companies. The ISA 570 is a pertinent element in the effort to reduce the incidents because it frames the way auditors conducts going concern assessment and GC opinion issuance process. We found no assessment on the impact of the latest ISA570 on GC opinion issuance rate has been made and this motivates us to start a discussion. The objectives of this paper are (1) to evaluate the evolution of the ISA 570 standard and to make sense of its possible impact on the rate of GC opinion issuance and (2) to highlight measures that can improve GC opinion issuance practice that policy makers and researchers could consider.

We hope this paper is a contribution in a way that it could become an input in the process of developing future promulgations related to going concern principle and could inculcate future academic studies in this area. The next section analyses the evolution of ISA 570 Going Concern adaptation in Malaysia. It is followed by a section that brings to light a number of matters that can be incorporated in auditing standards as well as other promulgations to reduce errors in GC opinion issuance. This paper is ended with a final conclusion.

\subsection{The Evolution of ISA 570}

We evaluate the evolution of ISA 570 through a historical analysis. The ISAs issued by International Federation of Accountants (IFAC) have been the basis of auditing standards in Malaysia since 1977, according to a source from Malaysian Institute of Certified Public Accountants [MICPA] (EStandardsForum, 2011). A major milestone in the adaptation of IFAC's auditing standards in Malaysia took place in 2003 when Malaysian Institute of Accountants (MIA) and MICPA formed a Joint Working Group on Auditing (JWG). The purpose of the working group is to issue new ISAs as well as to harmonize Malaysian auditing practices (Malaysian Institute of Accountants, 2003). However, not until October 2009, MIA via its report entitled 'IFAC Clarity Project Review' noted that "in line with the IFAC Clarity Project, Malaysia issued clarified ISAs as Exposure Drafts, and subsequently clarified ISAs were adopted as MASAs [Malaysian Approved Standards on Auditing] effective for periods beginning on or after January 1, 2010" (EStandardsForum, 2011). Until then, Malaysia is an active member of IFAC, with the purpose of gaining up to date auditing and accounting knowledge as well as contributing Malaysian input to this international accounting body (Malaysian Institute of Accountants, 2010).

With respect to auditing standard on GC opinion and assumption, none has been issued in Malaysia until the end of 1990s. Even though IFAC released International Auditing Guidelines 23 (IAG 23) in 1986, it was not adopted in Malaysia but taken as guidance only. IAG 23 is relatively small i.e. a seven pages document containing 16 paragraphs and covers topics on going concern assumption, audit evidence and auditors' report only (The International Federation of Accountants, 1986). The issuance of GC opinion by Malaysian auditors then was very much at their discretion; a situation comparable to Eastern European countries like Belgium at that time (Carcello, Vanstraelen, \& Willenborg, 2009). In July 1998 MIA adopted ISA 570 Going Concern and unlike IAG 23, this auditing standard was comprehensive. The ISA 570 (1998) required auditors to consider the appropriateness of client's going concern assumption. Events or conditions such as high net liability, adverse key financial ratios or negative operating cash flows have been mentioned as can cast material uncertainties that lead to significant doubt on going concern assumption. In the year 2000 IFAC initiated the revision of the ISA 570 (1998) and released new version of the standard two years later. The ISA 570 (2002) [39 paragraphs] is an addition to the 1998 version [18 paragraphs] particularly in terms of clarification about events and condition that may lead to significant doubt about client's GC assumption (International Federation of Accountants, 2002). Figure 1 below shows the timeline of auditing standard related to GC assumption applicable in Malaysia. 


$\begin{array}{cccc}\text { ISA } \mathbf{5 7 0} & \text { ISA } \mathbf{5 7 0} & \text { ISA } \mathbf{5 7 0} & \text { ISA } \mathbf{5 7 0} \\ \text { Effective: } & \text { Effective: } & \text { Effective: } & \text { Effective: } \\ \text { July } 1998 & \text { Jan 2002 } & \text { Jan 2010 } & \text { Dec 2016 }\end{array}$

\section{IAG 23}

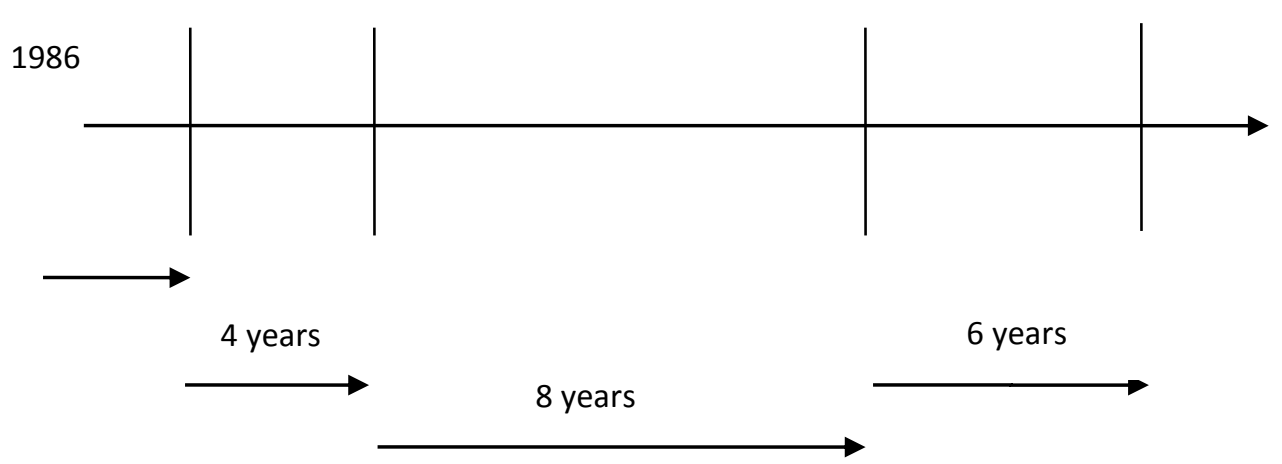

Figure 1: Auditing Standards on Going Concern Assumption

As shown in Figure 1, ISA 570 (2002) lasted eight years i.e. until its successor the ISA 570 (2010) was introduced. Ironically, the 2002 standard was effective for a long period of time even though significant events had happened particularly the billion dollar loss of stakeholders' money contributed partly by poor audit quality (Enron, WorldCom, etc) and the issuance of Sarbanes-Oxley Act in 2002 (Bellovary, Giacomino, \& Akers, 2007). The newly issued ISA 570 (2010) was a major departure from the former version. ISA 570 (2010) contains 24 paragraphs and ISA 570 (2002) contains 39 paragraphs, but, they are almost similar in thickness with the former having 16 pages and the latter has 19 pages (including appendixes) (International Federation of Accountants, 2010). Auditors' responsibility has been heightened in ISA 570 (2010) from only to 'consider' the appropriateness of client's GC assumption and disclosure practice in the earlier standard to "[1] obtain sufficient appropriate audit evidence about the appropriateness of management's use of the going concern assumption in the preparation and presentation of the financial statements and to [2] conclude whether there is a material uncertainty about the entity's ability to continue as a going concern" (para. 6). Furthermore, the new ISA 570 enhances auditor independence ${ }^{1}$ in deciding the appropriateness of GC assumption by promoting the auditor to communicate "their findings about the disability of client to continue as a going concern entity" with party that is in charge of governance like audit committee (para. 23). This is in line with Malaysian corporate governance promulgation such as MCCG 2007 (Securities Commission Malaysia, 2007) and Bursa Listing Rules (Bursa Malaysia, 2008) that require close working relationship between auditors and audit committee.

After the issuance of ISA 570 (2010) Going Concern, a Malaysian auditor may issue unqualified opinion with emphasis of matter, qualification or adverse opinion to a particular client according to the

\footnotetext{
${ }^{1}$ The audit committee can enhance auditor independence and consequently can help to increase audit quality(Knapp, 1985, 1987).
} 
appropriateness of GC assumption and the extent of disclosure made by the client in financial statement. The 'comfort' of issuing a 'disclaimer' like when ISA 570 (2002) is effective is no longer allowable (refer Table 1). This should be an applauded omission because 'disclaimer' implicitly means auditor declines to conclude opinion and hence protect themselves from any legal liability (Ismail \& Mustapha, 2011). Examples of events and conditions that may lead to the issuance of the GC opinion have increased in number. Specifically, ISA 570 (2010) provides 21 examples of conditions under three headings namely financial, operational and others while there were only 17 examples in ISA 570 (2002).

Table 1: Going Concern Opinion

\begin{tabular}{l|l|l|c|c}
\cline { 2 - 4 } \multicolumn{2}{c}{} & \multicolumn{3}{c}{ Audit Opinion } \\
\hline \multicolumn{2}{c}{ Audit Conclusion } & \multicolumn{1}{c}{$\begin{array}{c}\text { ISA 570 } \\
2016\end{array}$} & $\begin{array}{c}\text { ISA 570 } \\
2010\end{array}$ & $\begin{array}{c}\text { ISA 570 } \\
2002\end{array}$ \\
\hline \multirow{4}{*}{$\begin{array}{l}\text { 1. GC } \\
\text { assumption is }\end{array}$} & $\begin{array}{l}\text { BUT material } \\
\text { uncertainty about GC } \\
\text { exist and adequate } \\
\text { disclosure was made }\end{array}$ & $\begin{array}{l}\text { Unmodified } \\
\text { with a } \\
\text { 'Material } \\
\text { Uncertainty } \\
\text { Related to } \\
\text { Going } \\
\text { Concern' } \\
\text { section }\end{array}$ & $\begin{array}{l}\text { Unmodified } \\
\text { with Emphasis } \\
\text { of Matter } \\
\text { (OEM) }\end{array}$ & $\begin{array}{l}\text { Unmodified } \\
\text { with OEM or } \\
\text { Disclaimer }\end{array}$ \\
\cline { 2 - 5 } & $\begin{array}{l}\text { BUT material } \\
\text { uncertainty about GC } \\
\text { exist and adequate } \\
\text { disclosure was NOT } \\
\text { made }\end{array}$ & $\begin{array}{l}\text { Qualified or } \\
\text { Adverse } \\
\text { opinion }\end{array}$ & $\begin{array}{l}\text { Qualified } \\
\text { opinion }\end{array}$ & $\begin{array}{l}\text { Qualified } \\
\text { opinion }\end{array}$ \\
\hline $\begin{array}{l}\text { 2. GC assumption is NOT appropriate } \\
\text { BUT prepare financial statement like GC } \\
\text { assumption is appropriate }\end{array}$ & $\begin{array}{l}\text { Adverse } \\
\text { opinion }\end{array}$ & $\begin{array}{l}\text { Adverse } \\
\text { opinion }\end{array}$ & $\begin{array}{l}\text { Adverse } \\
\text { opinion }\end{array}$ \\
\hline
\end{tabular}

The latest ISA 570 (2016) has been released by the International Federation of Accountants (IFAC) and has been made effective in Malaysia starting from 15 December 2016 (International Federation of Accountants, 2015). ISA 570 (2016) contains 26 paragraphs and it is 24 pages thick including the appendixes, almost no difference compared to ISA 570 (2010) of 24 paragraphs and 16 pages. Two roles of auditor mentioned in the ISA 570 (2016) are to "[1] to obtain sufficient appropriate audit evidence regarding, and conclude on, the appropriateness of management's use of the going concern basis of accounting in the preparation of the financial statements, and to conclude, based on the audit evidence obtained, whether a material uncertainty exists about the entity's ability to continue as a going concern" (para. 6). In ISA 570 (2010), however, the first role of auditors is to obtain adequate evidence only, no requirement to conclude about the adequacy of the evidence. Here in ISA 570 (2016) auditors have to not only ascertain the appropriateness of management's application of going concern assumption but also to conclude on the appropriateness of the application of such accounting principle. Paragraph 17 and 19 of this latest ISA 570 clarified the new roles further. 
Same like ISA 570 (2010), the latest standard provides a total of 21 examples of events and condition that may cast significant doubt about the ability of an entity to continue to operate in the future. As shown in Table 1, after the release of this ISA 570 (2016), auditor should issue Unmodified opinion with a 'Material Uncertainty Related to Going Concern' section when GC assumption is appropriate in financial statement preparation but material uncertainty about GC exist and adequate disclosure has been made; this is more specific reference to the accounting principle compared to the prior version of ISA 570 (2010) in which auditor is expected to issue Unmodified opinion with an EOM. In the event where GC assumption is appropriate in financial statement preparation but material uncertainty about GC exists and management made no adequate disclosure, the auditor is expected to issue Qualified or Adverse opinion. Consistent with ISA 570 (2002) and (2010), this latest standard set that when GC assumption is not appropriate but a client prepared financial statement like the assumption is appropriate then auditor has to issue an Adverse opinion.

There would be an increase in the rate of GC opinion issuance after a new and strict auditing standard is released; this happens in US (Ryu, Uliss, \& Roh, 2009), in UK (Citron \& Taffler, 2004) and China (DeFond, Wong, \& Li, 1999). As it has been analyzed above, we believe that Malaysian situation is dissimilar to US, UK and China. Given that ISA 570 (2016) is no different in strictness compared to ISA 570 (2010), no significant change in the rate of GC opinion issuance in Malaysia can be expected.

\subsection{Points to Contemplate}

The second objective of this paper is to highlight measures that could improve the GC opinion issuance practice in our country. There are several that we believed can be considered:

1. GC opinion should be issued if there is doubt about the ability of a company to continue operation and thus there must be an objective measure of probability of failure if the issuance of GC opinion is to be made accurately. For instance, in auditing standard there should be a clear and objective indicator like when Altman z-score of a client is -1 or less, it is compulsory for an auditor to issue GC opinion. Previous researchers suggested that a more objective auditing standard (which can cause less auditor discretion) could lead to a more accurate GC opinion issuance (Vanstraelen, 2000, 2002, 2003).

2. The law and regulation can be utilized to solve the problem of Malaysian auditors tend to not issue GC opinion appropriately. The auditing and accounting standard in a way allow auditor to use discretion (which can be clouded by self-interest), law and regulation on the other hand allow firm enforcement (Kydland \& Prescott, 1977). The enforcement of law is a proven success in a less litigious context to reduce the practice of not issuing GC opinion to client that is supposed to receive it (see Carcello, et al., 2009). The law and regulations can be designed to punish auditors who are deliberately do not issue GC opinion to clients that have material uncertainty about going concern.

3. In ISA 570 (2016) it was emphasized that management plan is the most important element in the assessment of the appropriateness of GC assumption of a client company. These standards mentioned that auditor shall review management plan when he is at audit planning stage, at evaluating management assessment of GC assumption, when assessing the appropriateness of the assumption, when conducting additional procedure and when making audit conclusion. However, we in the opinion that reliance too much on management (plan) can be fatal to the possibility of appropriate GC opinion issuance. This is because considering management's plan exposes auditor to negotiation with management and it is not rare that in negotiations auditor would follow what management wants (see Knapp, 1985, 1987). And management most of the time would want a clean audit opinion. 
4. There should be additional regulations and/or standards tailored specifically for companies that are significantly owned by either management, family or institutions because these three groups of owners have different ways in influencing the GC opinion issuance process (see Osman, 2016). For instance, companies with significant management ownership (i.e. very influential management) should have a specific committee for minority shareholders within their board of directors (minority shareholders committee should be a good name) that can act as a check and balance mechanism to curb the management practice of dampening auditors' propensity to issue GC opinion.

\subsection{Summary and Conclusion}

Overall, we are in the opinion that there is no strong ground to expect the new ISA (2016) can reduce the problem of Malaysian auditor do not issue GC opinion to a very large percentage of seriously financially distress companies. This is because there is no new stricter measure has been introduced in the latest ISA 570 (2016). However, Malaysian policy makers and standard setters still have at least four measures if they want to improve the rate and practice of GC opinion issuance in this country. The measures include - (1) to introduce more objective tool to be used when auditor assessing the going concern status of a client (e.g., Altman z-score), (2) to utilize law and regulation to punish auditors who deliberately issue a clean audit opinion to companies that have material uncertainty about going concern, (3) to recommend auditor to rely less on management plan and (4) to prescribe auditor with guidelines to help them to deal with influential stakeholders during GC opinion issuance process. Researchers on the other hand should examine the effectiveness of the new ISA 570 (2016), at least. 


\section{References}

Abdul Wahab, E. A., Mat Zain, M., \& Abdul Rahman, R. (2013). Political connections, fees paid to auditors and auditor independence in Malaysia: evidence from going concern audit opinion. International Journal of Accounting, Auditing and Performance Evaluation, 9(2), 153-183.

Accountants Today (December 2009). Financial reporting: Concern over 'Going concern'?, 18-21.

Accountants Today (May/June 2012). Upholding financial feporting quality, 22-26.

Accountants Today (November 2010). Financial Statements Review Committee (FSRC) key observations, 26-30.

Accountants Today (November, 2009). Lessons from deficient disclosure, 14-17.

Bellovary, J. L., Giacomino, D. E., \& Akers, M. D. (2007). A review of going concern prediction studies: 1976 to present. Journal of Business \& Economics Research(5), 9-28.

Bursa Malaysia (2008). Chapter 5 Organisation and structure of participating organizations Retrieved August 20, 2008, from http://www.bursamalaysia.com/website/bm/rules_and_regulations/ $\geq$

Carcello, J. V., Vanstraelen, A., \& Willenborg, M. (2009). Rules rather than discretion in audit standards: Goingconcern opinions in Belgium. The Accounting Review, 84(5), 1395-1428.

Citron, D. B., \& Taffler, R. J. (2004). The comparative impact of an audit report standard and an audit goingconcern standard on going-concern disclosure rates. Auditing: A Journal of Practice \& Theory, 23(2), 119130.

DeFond, M. L., Wong, T., \& Li, S. (1999). The impact of improved auditor independence on audit market concentration in China. Journal of Accounting and Economics, 28(December), 269-305.

$\begin{array}{llllll}\text { EStandardsForum } & \text { (2011). } & \text { Malaysia } & \text { Retrieved } & 18 & \text { July, }\end{array}$ www.estandardsforum.org/malaysia/standards/international-standards-on-auditing

International Federation of Accountants (2002). ISA 570 Going concern. Kuala Lumpur: The Malaysian Institute of Certified Public Accountants.

International Federation of Accountants (2010). ISA 570, Going Concern. Kuala Lumpur: Malaysian Institute of Accountants.

International Federation of Accountants (2015). ISA 570, Going Concern (Revised). Kuala Lumpur: Malaysian Institute of Accountants.

Ismail, H., \& Mustapha, M. (2011). Disclaimer audit reports among Malaysian listed companies. Paper presented at the 5th IIUM International Accounting Conference, Kuala Lumpur, Malaysia.

Knapp, M. C. (1985). Audit conflict: An empirical study of the perceived ability of auditors to resist management pressure. The Accounting Review, 60(2), 202-211.

Knapp, M. C. (1987). An empirical study of audit committee support for auditors involved in technical disputes with client management. The Accounting Review, 62(3), 578-588.

Kydland, F., \& Prescott, E. (1977). Rules rather than discretion: The inconsistency of optimal plans. The Journal of Political Economy 106(December), 1113-1155.

Malaysian Institute of Accountants (2003). 2003 Annual report and financial statements. Kuala Lumpur: Malaysian Institute of Accountants.

Malaysian Institute of Accountants (2010). Annual report 2010. Kuala Lumpur: Malaysian Institute of Accountants.

Osman, M. N. H. (2016). Effects of client probability of failure, auditor characteristics, ownership structure on issuance of going concern opinion. Unpublished doctoral thesis, Universiti Putra Malaysia, UPM Serdang.

Osman, M. N. H., Turmin, S. Z., Muhamad, H., \& Hussain, R. (2016). Auditor characteristics and the issuance of going concern opinion. International Business Management, 10(17), 3733-5250.

Ryu, T. G., Uliss, B., \& Roh, C. (2009). The effect of the Sarbanes-Oxley Act on auditors' audit performance. Journal of Finance and Accountancy, 1(August), 1-7.

Securities Commission Malaysia (2007). Malaysian Code on Corporate Governance (Revised 2007). Kuala Lumpur: Secuities Commission.

The International Federation of Accountants (1986). IAG 23 Going concern. New York: The International Federation of Accountants.

Vanstraelen, A. (2000). Impact of renewable long-term audit mandates on audit quality. The European Accounting Review, 9(3), 419-422.

Vanstraelen, A. (2002). Auditor economic incentives and going concern opinions in a limited litigious Continental European business environment: Empirical evidence from Belgium. Accounting and Business Research, 32(3), 171-186.

Vanstraelen, A. (2003). Going concern opinions, auditor switching, and self fulfilling prophecy effect examined in the regulatory context of Belgium. Journal of Accounting, Auditing \& Finance, 18(Spring), 231-253. 